\title{
РИТУАЛЬНЫЕ ДЕЙСТВИЯ В ОХОТНИЧЬЕЙ СУБКУЛЬТУРЕ ОСЕТИН
}

\begin{abstract}
А.Б. Багаев
Мировоззренческие установки, практикуемые и транстируемые мужскими сообществами, в значительной степени влияют на социализацию личности, а, следовательно, и на развитие общества. Вследствие этого всестороннее исследование мужских субкультур весьма актуально. Субкультура всегда основана на одной или нескольких предыљущих субкультурах, видоизменившихся под воздействием различных факторов. По этой причине для понимания путей дальнейтего развития современного общества актуально изучение бытовавших ранее субкультур. Одним из базовых элементов субкультур прошлого были ритуальные действия. Ритуальные действия имели выраженное внешнее оформление и глубокий внутренний смысл. В данной статье исследуются ритуальные действия и формы обрядового поведения в охотничьей субкультуре в традиционном осетинском обществе. Рассматриваемая субкультура относится к мужским профессиональным субкультурам. Влияние транслируемых ею ценностей прослеживается как в духовной, так и в материальной культуре осетинского этноса. Научная новизна работы определяется тем, что она является первым комплексным исследованием ритуальных действий в охотничвей субкультуре осетин. Источниками при разработке поставленной проблемы послужили этнографический материал, фольклорные тексты и данные осетинского языка. При разработке поставленной проблемы были рассмотрены ритуально-обрядовые формы поведения осетинских охотников в разных ситуачиях. Проанализирован обряд и ритуальные действия охотничвей группы перед началом охоты, у осетин разных обществ. Установлены особенности ритуального поведения охотника, охранявщего тагерь во время поиска его товарищами дичи. Определены ритуальные действия, связанные с временным охотничьим жилищем. Выявлены особенности ритуального поведения и обряд, проводивщийся после удачной охоты. Выцелены обрядовые действия и ритуалы, которые проводились охотниками в населенном пункте после охоть. Описан обряд, использовавшийся осетинскими охотниками для снятия порчи.
\end{abstract}

Ключевые слова: ритуальные действия, осетинский охотник, Афсати, молитвословие, охотничий посох.

В древности в жизни многих народов охота занимала важное место. В ходе многовековой практики были выработаны особые обряды и обычаи, тайный охотничий язык. По представлению охотников, удача на охоте во многом зависит от строгого соблюдения ритуально-обрядовых форм поведения. Комплексное исследование охотничьих обрядов и обычаев, являющихся элементами традиционной культуры, позволяет лучше осветить этническую историю и культуру народа.

В прошлом в жизни осетин охота также играла большую роль. Так, по свидетельству Н.Г. Берзенова: «охоту они счи- тают за самое священное и молодеческое занятие, в котором, главным образом, действует счастье; тот, кто проворен и удачен на охоте, почитался у них самым счастливым и уважаемым человеком» [1, 94]. В осетинском нартовском эпосе охота является любимым занятием не только нартов, но также и небожителей, в частности, Уастырджи, который охотится верхом и с собаками $[2,18]$.

Одним из первых авторов, обратившим внимание на обычаи и обряды, связанные с охотой, был Г.М. Цаголов [3]. В небольшой этнографической заметке он отразил наиболее известные обычаи и об- 
ряды осетинских охотников. Интересные сведения по рассматриваемой проблеме содержатся в этнографическом очерке Г.Ф. Чурсина «Осетины» [4]. Собранный им материал весьма ценен: некоторые из зафиксированных им обычаев и обрядов больше нигде не упоминаются. Ценным трудом по исследуемому вопросу является рукопись Б.А. Алборова «Язык осетинских охотников». Работа посвящена исследованию охотничьего языка у осетин, но в ней получили освещение также отдельные охотничьи обычаи и обряды [5]. Определенный научный интерес представляет книга В.А. Кесаева «Обряды и язык осетинских охотников» [6]. Автором собран разнообразный материал об обычаях, обрядах и языке осетинских охотников, весьма важный для изучения охотничьей субкультуры осетин. Отчасти рассматриваемый вопрос затронут и в работах по традиционной культуре и языку осетинского народа $[7 ; 8 ; 9 ; 10 ; 11$; $12 ; 13]$.

По причине того, что удача на охоте зависела от многих обстоятельств и случайностей, она была окружена многочисленными обрядами и ритуальными действиями. Во время застолья старшие всегда обращались к Богу и Уастырджи, в своих молитвах просили, чтобы охотники шли по дороге удачи, чтобы из скота Афсати они всегда получали долю $[6,31]$.

Согласно религиозным воззрениям осетин, исход охоты зависел от благосклонности и великодушия покровителя диких животных и охотников Афсати (Æøсати). В прошлом осетины считали, что дикие животные, на которых они охотились, находятся в полной власти Афсати. В народе свято верили в то, что покровитель диких животных благосклонен к бедным охотникам, которые неукоснительно исполняли охотничьи обряды [13, 1006].

Рядом с местом охоты, охотники выбирали место для стоянки (логдон). Для этой цели могли использовать пещеру.
Если подходящей пещеры не было, тогда ставили шалаш на небольшой лужайке. Сюда приносили тушу добытого животного, разделывали ее. Если охота оказывалась неудачной, то здесь отдыхали до следующего утра.

Расположившись в определенном месте, охотники одного из своих товарищей выбирала на должность караульного, охраняющего стоянку (бынатгсес). Обычно это был один из молодых охотников. Он обязан был охранять охотничий лагерь, приготовить дрова, воду, разжечь костер. Кроме этого, он определенными ритуальными действиями оказывал помощь своим товарищам. Так, нормы охотничьей субкультуры осетин предписывали охотнику, оставшемуся в лагере вести себя тихо. Ему категорически запрещалось свистеть, кричать, петь. Весь период времени, пока охотники были вне лагеря, он должен был воздерживаться от принятия пищи и питья воды [7, 117]. Исполняя эти ритуальные действия, охотник верил, что Афсати видит тяжелое положение терпящего лишения и обязательно поможет ему. Спокойным поведением постившийся охотник демонстрировал благонравие и терпение, а, как известно, Афсати благоволил к непритязательным и скромным охотникам. Таким образом, по религиозным представлениям осетин, ритуальные действия охотника оставшегося в лагере должны были способствовать успеху всей группы в охоте.

После определения караульного в лагере охотники разводили огонь и рассаживались строго по старшинству. При этом, самый старший из них всегда сидел лицом на восток. В одних ущельях охотники рассаживались вокруг костра кругом [14, 237], в других они садились параллельными рядами, так, чтобы костер находился посередине [3].

Отправляясь на охоту, охотники несли с собой осетинские пироги с сыром (уселивых), которые предназначались для обрядового действия и молитвы покро- 
вителю диких животных, чтобы он был доброжелательным к охотникам. Ритуальное действие начиналось после того, как охотники располагались на стоянке и разжигали костер. Три осетинских обрядовых пирога ставили перед самым старшим охотником, стоявшим лицом на восток. Он снимал шапку, брал в руку рог с аракой и с благоговением начинал молитвословить $[4,199]$. Текст молитвы всегда был импровизированным, но смысл его был примерно одинаковый. Доступный нам вариант молитвы был записан от старого охотника и содержит следующие слова: «Сидящий высоко над лесами Афсати обрати на нас свой взор, посмотри на нас. Над березовым лесом пасется множество оленей (в осетинском тексте они обозначены охотничьим словом ставдбкрзжйджынтюе букв. «мощношейные»). Дай нам из них! Дай, что дашь, то без сожаления дай! И впредь относись к нам благожелательно Афсати! У тебя же много. Вон пасутся над кленовым лесом. Дай нам, дай, господин господ Афсати, крепкорогих горных туров! Вон в лиственном лесу пасется много кабанов (в осетинском тексте использовано охотничье слово хъозыдюндагджынтю). Дай нам из них, дай, Афсати! Что дашь нам, то дай в сухом месте, чтобы сухие дрова и вода там тоже были! Когда появится первый луч солнца, по узкому горному гребню гони их к нам, Афсати. Мы сами, без твоей помощи малым числом ничего не сможем!» $[5,19 ; 6,91]$. Данный ритуальный текст свидетельствует о том, что основной темой молитвословий была просьба к Афсати проявить благосклонность к охотникам, максимально облегчить им добычу крупного животного из многочисленных его стад.

Другие охотники, тоже без шапок, исполненные сознания важности и значительности происходящего внимательно слушали старшего. После каждого отрезка речи с законченной интонацией, они вместе восклицали: «оммен» («аминь»).
Использовались и другие слова, имеющие обрядовый характер, и словосочетания: «табу йжхицжн!! («слава ему»), «табу дын кжнюем, Æфсати!» («славим тебя, Афсати!»), «нке табу дюе фехъyысқљ!» («наша хвала пусть будет услышана тобой!»), «мах де уазсег, Æфсати, табу дехииянн!» («мы просим твоего покровительства, слава тебе, Афсати!») [5, $20 ; 6,91]$. Все эти фразы говорят о единстве мыслей и стремлений всех охотников, о глубоком почитании и особом уважительном отношении охотников к покровителю диких животных. Описанное ритуальное действие должно было обеспечить удачную охоту.

Описанный обряд был известен не во всех осетинских ущельях. Однако в смысловом плане похожие обряды совершали все осетинские охотники. Так, в западной части Осетии, в ущелье известном как Уаллагком, каждый из охотников, отправлявшихся на охоту, клал в свою походную сумку маленькие обрядовые пироги продолговатой формы (гуылтсе). На рассвете, после того как охотники оказывались на месте стоянки высоко в горах, приступали к молитве. Возносил молитву самый старший группы. В самом начале он обращался к Богу и Уастырджи. После этого возносил молитву к Афсати, чтобы тот даровал бедным охотникам мясо на шашлык. В молитве по отношению к Афсати использовался эпитет nырpыкрихи, который переводится на русский язык как «тот, у кого волосы усов торчат в разные стороны». Ритуал завершался тем, что старый охотник бросал в сторону находившихся ниже горных вершин обрядовые пироги, которыми молился. Он исполнял это действие со словами, обращенными к Афсати: «А вот эти обрядовые пироги предназначаются твоему маленькому сыну» $[6,96]$.

В ритуальных церемониях осетинских охотников особую роль играли традиционные алкогольные напитки (пиво, арака, брага). Обуславливалось это тем, 
что по религиозным представлениям осетин, молитва не имеет ритуальной силы, если она произведена без использования алкогольного напитка $[15,93]$. Наиболее ритуально-престижным напитком считалось осетинское пиво. Оно употреблялось при проведении обрядовой трапезы во время всех осетинских народных праздников.

В ритуальных действиях, предшествовавших охоте, строго исключалось мясо. По представлениям охотников, если на столе будет мясо, то Афсати ничего им больше не даст.

В осетинской охотничьей субкультуре существовали определенные обряды, связанные с жилищем, в котором охотники пребывали во время охоты. Так, если группа размещались в пещере, то перед тем как войти в нее каждый охотник молился Уастырджи пещеры (Логсеть Уастьрджи) и духу-хозяину данного места (Бынатыхицау), прося у них защиты и покровительства. Если же жили в шалаше, обращались только к духу-хозяину этого места. Порог жилища нужно было переступать только правой ногой. Перед тем как войти, охотник должен был оставить свои вещи (сумку, ружье и посох) с внешней стороны шалаша или пещеры. И лишь после того, как он совершал вышеописанные ритуальные действия, он мог занести свои вещи во временное жилище. Определенные правила были и при занесении туда туши дичи. Ее надо было заносить только головой вперед, а размещать исключительно в правой части жилища.

После успешной охоты охотники направлялись в свой лагерь. Караульный всегда встречал их и обязательно на охотничьем языке спрашивал о том, как прошла охота, они должны были дать ему ответ на том же языке. Далее ему передавали тушу, и он разводил огонь. Все необходимое у него было заранее готово. Из небольших кусков легких животного, которые оборачивались в кусочки наре- занного брюшного жира, караульный на деревянном вертеле готовил ритуальный шашлык (сехсырфоембкелтюе) [7, 117-118].

Большое значение имело то, из какого древесного материала изготовлен вертел для ритуального шашлыка. По религиозным представлениям осетин наиболее подходящим, то есть ритуально чистым деревом считалась береза. Если не было березы, то вертел изготовляли из веток дикой груши или яблони. В случае их отсутствия брали древесину лесного ореха.

Количество кусков мяса на вертеле было строго нечетным (три, пять, семь). Когда шашлык был готов, караульный подносил вертел старшему. При этом ручка вертела всегда была обернута травой. Делалось это для того, чтобы не оскорбить Афсати. По представлениям охотников, покровитель диких животных прогневается, если молящийся ему прикоснется кожей рук к древесине вертела. Старший в своем молитвословии обращался к Богу и к Афсати. Благодарил за преподнесенный бедным охотникам дар и просил покровительствовать им и в будущем. Закончив молитвословить, старший вручал рог с напитком и вертел с шашлыком самому младшему охотнику. Тот отпивал глоток ритуального напитка из рога и пробовал шашлык. Потом он освобождал вертел от мяса и ломал его со словами: «Пусть будет нам такое счастье, чтобы и завтра мне надо было сломать вертел!». Сломанный вертел сжигали на том же костре, на котором приготовлен был шашлык [7, 118]. После этих ритуальных действий каждый из охотников ел кусок шашлыка, а после приступали к обрядовой трапезе.

Наиболее почетные части туши животного (голова, шея и сердце) охотник, убивший животное, обязательно должен был забрать домой. Вероятно, это делалось по причине того, что согласно архаическим представлениям, эти части туши животного были мощным источником жизненной силы, в особенности голова. 
Принесение их в поселение и употребление в пищу с проведением соответствующего ритуала должно было принести всей общине благополучие, изобилие и плодородие. Согласно осетинскому возрастному субкультурному комплексу, голова, шея и сердце относились к пище старших (хистсерты хсейттсе). Они "всегда подаются старшему за столом и общему дележу между присутствующими никогда не подлежат; часто даже отправляются из дома к соседям, если где имеется почетный старик» $[16,541]$. Когда охотник приходил домой, глава семьи поручал младшим пригласить в дом старших селения, а также родственников и знакомых. В доме происходило ритуальное застолье согласно осетинским обычаям. Голова, шея и сердце были размещены на пиршественном столе перед старшими. При этом место расположения каждой из этих частей туши тоже было строго регламентировано. Голова ставилась посередине, слева от него располагалась шея, а справа - сердце $[6,98]$. Авторитет охотника, добывшего животное, в глазах общества существенно возрастал. Так как считалось, что чем мощнее и красивее вышеозначенные части животного, тем больше их жизненная сила, охотники старались добывать крупных, головастых оленей и туров.

Молодой охотник после первой удачной охоты из туши добытого животного (олень, горный тур, зубр) обязан был сделать ритуальное пиршество и поблагодарить высшие силы за свой успех. В своих молитвах за ритуальным столом старшие просили высшие силы, в особенности Афсати, и дальше оказывать свое покровительство юному охотнику. После завершения ритуализированного пира голова дичи устанавливалась в святилище. По религиозным представлениям осетин это увеличивало эффективность совершенных ритуальных действий.

Некоторые интересные обряды охотничьей магии, которые были известны старым и опытным охотникам, нашли от- ражение в нартовском эпосе осетин. Так, в одном из сказаний о нарте Хамыце есть весьма занимательный момент. Во время охоты нарту удалось подстрелить серну. Хамыц приносит тушу в нартовское селение, свежует его, делит на части и, таким образом, раздает своим соседям. Жившая по соседству с прославленным нартом ведунья тоже ждала доли, но Хамыц про нее не вспомнил. Это не понравилось ведунье и, зайдя в дом Хамыца, она тайком взяла оттуда клочок шкуры и косточку серны и произнесла над ними заклинание: «Пусть с этого дня бог более не даст тебе доли из животных Афсати!» С этого времени охотничье счастье покинуло Хамыца. Через некоторое время он осознал, что стал жертвой колдовства. Славный нарт пошел к другой ведунье, которая раскрыла ему причину, по которой удача покинула его. Хамыц настойчиво потребовал от нее содействия в нейтрализации воздействия вредоносной магии. Следуя советам ведуньи, он приготовил три маленьких обрядовых пирога с сырной начинкой и хмельные ворсинки. Далее нарт отправился в дремучий лес и, достигнув первого могучего дерева, разместился под ним и начал молиться. Потом он бросил в две противоположные стороны два обрядовых пирога, как его научила ведунья, третий же съел. Затем дунув на хмельные ворсинки, проговорил магический текст: «Пускай с сегодняшнего дня я буду расколдован. Как эти хмельные ворсинки отделились от тарелки, так же пусть проклятие и чары, наложенные на меня, отделятся от меня». После проведения этого ритуально-магического действия удача на охоте опять стала сопутствовать Хамыцу [17, 444].

Один из важных и устойчивых ритуальных действий в субкультуре осетинских охотников бы связан с долей первого встречного (сембселсеггаджы хай) [4, 199]. Не во всех районах Осетии часть туши дичи, преподносимая в дар первому встречному, была одинаковой. В неко- 
торых ущельях эту долю составляли три левых передних ребра, в других это были три правых передних ребра. В некоторых местностях в качестве доли первого встречного обязательно давали огузок, а в других - рассматриваемая доля вообще не была строго фиксирована $[6,81]$. Как видно по самому названию доли, она всегда вручалась человеку, который первым оказывался на пути охотников, возвращавшихся в селение. Когда охотники двигались группой, то рассматриваемую долю должен был обязательно нести самый младший из них.

Повстречав по дороге домой человека, охотники останавливались, радостно приветствовали его и торжественно преподносили ему положенную долю. Он почтительно брал его. Потом он произносил: «Аффсатийы фоссей хайджын уm!» - Пусть у вас всегда будет доля из стада Афсати!» Говоря это, он рвал траву или веточки дерева и бросал их на тушу дичи. Данное ритуально-магическое действие было направлено на то, чтобы охотникам всегда сопутствовал успех на охоте. Согласно религиозным представлениям осетинских охотников, это благопожелание обязательно донесется до Афсати, и он щедро одарит добычей их и в будущем.

Даже в том случае, когда никто им не встречался на пути, долю ни в коем случае нельзя было нести домой, потому что Афсати посчитает охотников жадными и лишит их своего покровительства. Поэтому, если никого не встречали, то долю первого встречного несли в первый же двор поселения и торжественно вручали старшему мужчине в семье. Получатель доли первого встречного принимал его с благодарностью. Он варил его, накрывал ритуальный стол и возносил молитву Афсати, за то, что он одарил охотников частью своего скота.

Ритуальное действие, направленное на пожелание обилия дичи и удачи на охоте, исполняли охотники, когда кто-то из них делал удачный выстрел. Все, кто был свидетелем этого, собирали в руку пучок травы или веточки и, подойдя к туше убитого животного, бросали их на него со словами: «Усе бирсе дьн радта AEøcamu!» - «Пусть много даст тебе Афсати». В отдельных местностях Осетии имя покровителя диких животных заменяли названием единого бога. Распространенной магической формулой, которая произносилась при исполнении описанного ритуального действия, звучала так: «Йсе хъуьн, йсе сердуйь бсери, дьн радтсед $А$ бcamu!» - «Равное количеству волосинок в шкуре убитого животного, пусть даст Афсати!» На это охотник, добывший зверя, обязательно отвечал так: «Ксед нын дсетты, усед нын иумсе радтсед». - «Если он даст нам, тогда пускай даст нам это всем вместе» $[6,89]$. По представлениям охотников, описанное ритуальное действие способствует удаче в охоте в будущем.

Архаическое мышление, характерное для людей прошлого, предполагало тесную связь между человеком и его вещами. Каждая вещь кроме утилитарных функций обладала еще и знаковыми. У осетинских охотников одним из таких вещей был охотничий посох (лседзег). Согласно нормам осетинской охотничьей субкультуры, каждый охотник должен был иметь посох и наносить на него отметину всякий раз, когда он добывал животное. В этом плане посох выполнял информативную функцию, наглядно демонстрируя потенциальные профессиональные способности своего обладателя в охотничьей деятельности. В обязательном порядке после добычи сотого зверя, охотник устраивал обрядовый пир. В охотничьей субкультуре осетин с посохом были связаны определенные поверья, согласно которым утеря посоха была для его обладателя предупредительным знаком свыше. Считалось, что он добыл допустимое количество зверя. С этого дня охотник должен был перестать ходить на охоту. Перерыв этот был продолжитель- 
ностью в три недели. Все это время он не просто сидел дома, а держал траур по убитым животным.

Среди ритуально-обрядовых форм поведения практиковавшихся осетинами-охотниками били и такие, которые способствовали единению носителей охотничьей субкультуры. В прошлом, в каждом осетинском обществе охотники организовывали культовое пиршество (куывд) в честь Афсати. Так, каждый год осенью жившие в Куртатинском ущелье (РСО-Алания) охотники справляли праздник, который назывался Бурседзуарыбон [6, 90]. К празднику каждая семья, в которой был охотник, на устройство ритуального застолья выделяла определенную меру зерна, по чаше со двора (къусбар). Собираемое подворно зерно для общего праздника являлось олицетворением понимания охотниками своего субкультурного единства. Другим символом, обозначавшим осознание охотниками своей общности, было жертвенное животное (ньцвонд). Охотники совместно приобретали большого быка и в день праздника в честь своего небесного покровителя Афсати совершали коллективное жертвоприношение. Мясо жертвенного животного варили в большом котле, кроме того готовили из него ритуальный шашлык. Каждый из охотников должен был из своего дома принести на праздник три осетинских ритуальных пирога с сыром, а из напитков пиво и араку. Когда все было готово к началу ритуального действа, охотники рассаживались за пиршественным столом с двух сторон строго по старшинству. Самый старший, располагавшийся во главе стола, вставал, и за ним вставали все, сидевшие за столом. В правую руку он брал рог с аракой, в то время как в левой руке у него был шампур с ритуальным шашлыком и с торжественным видом начинал молитвословить. Молитва его была направлена к Афсати, чтобы он никогда не лишал охотников своей благосклонности, и всегда покровительствовал им. После завершения каждого предложения старшего, все остальные совместно громко произносили сердечное «аминь» («оммен Хуыцау») или «слава ему» («табу йсехицсен»). Когда старший завершал молитвословить, то он передавал рог с аракой и шампур с шашлыком самому младшему, который согласно ритуалу должен был откусить от шашлыка и отпить из рога (ацаходын) $[6,90]$. После этого, все приступали к ритуальной трапезе.

Охотничье празднество всегда было веселым и оживленным. Кроме общей обрядовой трапезы важное место в охотничьем празднике отводилось разнообразным играм и развлечениям. Несмотря на то, что внешне охотничьи игры носили зрелищно-увеселительный характер, ритуально-обрядовое значение их не должно вызывать сомнения.

Другим важным элементом в охотничьем празднике являлись песни, музыка, танцы. Участники праздника старшего и среднего возрастов пели охотничьи песни. Главенствующее место среди них занимали песни об Афсати. Кроме широко известных священных гимнов, посвященных покровителю диких животных и охотников, исполнялись и песни, которые сочинялись в момент исполнения. Характерными словами в текстах священных гимнов были: «О покровитель зверей Афсати, щедро надели нас бесчисленными стадами своих зверей. Мясом своих животных ты насыщаешь нас. Накорми досыта нас и надели нас своими несметными стадами и отарами! Ты - отрада наша и хранитель нашей жизни защитник наших животных! О святейший Афсати! Надели нас щедро своей рукой, своими многочисленными стадами! Ты бог их! Ты властитель их!» [17, 681-682].

Молодежь исполняла народные танцы, среди которых архаичный танец охотников занимал центральное место. Он состоял из стилизованных элементов, отражавших удачную охоту. Следо- 
вательно, песни, музыка и танцы так же выступали формой ритуального поведения.

Таким образом, рассмотренные ритуально-обрядовые действия были важным компонентом охотничьей субкультуры осетин. Охота начиналась и заканчивалась ритуальными действиями. Несмотря на различие форм обрядовых действий в разных местностях Осетии смысл многих из них один и тот же. Анализ ритуальных действий в охотничьей субкультуре показал, что все они направлены были на обеспечение успеха в охоте.
Обязательным условием для успеха было правильное исполнение обряда. Только при уверенности в том, что ритуал проведен правильно, охотник начинал ощущать себя сильным, становился уверенным в своем успехе. Глубинный смысл обряда был известен только знающим людям, как правило, это были представители старшего поколения. Отдельные ритуальные действия охотничьей субкультуры, проводившиеся в поселениях, были направлены на обеспечение благополучия, изобилия и плодородия всей общины.

1. Берзенов Н.Г. Новый год у осетин Владикавказского округа // Периодическая печать Кавказа об Осетии и осетинах. Цхинвал, 1981. Т. І. С. 92-95.

2. Нартовские сказания. Эпос осетинского народа. Владикавказ, 2003. Кн.1.

3. Цаголов Г.М. Охотничий язык и обряды у осетин // Терские ведомости. 1895. № 58 .

4. Чурсин Г.Ф. Осетины. Юго-Осетия. Тифлис. 1924. С. 132-232.

5. Научный архив СОИГСИ. Ф.19. Оп.1. Д. 140.

6. Кесаев В.А. Обряды и язык осетинских охотников. Владикавказ, 1998.

7. Магометов А.Х. Культура и быт осетинского народа. Орджоникидзе, 1968.

8. Калоев Б.А. Осетины. М., 2004.

9. Чибиров Л.А. Традиционная духовная культура осетин. Владикавказ, 2008.

10. Техов Ф.Д. Охотничий язык у осетин // Известия ЮОНИИ. Вып.17. 1972. C. 121-137.

11. Хадикова А.Х. Этнические образы и традиционные модели поведения осетин. Владикавказ, 2015.

12. Гаглоева 3.Д. Охота в верованиях и обычаях осетин и сванов // Известия ЮОНИИ. 1987. Вып. 31. С. 49-57.

13. Кусаева 3.К. Мифо-фольклорные традиции в осетинской литературе // Фундаментальные исследования. 2013. №4-4. С. 1005-1010.

14. Хетагуров К.Л. Избранное. М., 1959.

15. Бедоева И.А. Традиционные хмельные напитки осетин (XIX-XX вв.). Владикавказ, 2014.

16. Кокиев С.В. Записки о быте осетин // Периодическая печать Кавказа об Осетии и осетинах. Владикавказ, 2014. Кн.7. С. 521-547.

17. Нартовские сказания. Эпос осетинского народа. Владикавказ, 2005. Кн. 3.

Bagaev, Alan B. - V.I. Abaev North Ossetian Institute for Humanitarian and Social Studies of the Vladikavkaz Scientific Centre of RAS (Vladikavkaz, Russia); alon.baga@mail.ru 


\section{RITUAL ACTIONS IN THE HUNTING SUBCULTURE OF THE OSSETIANS.}

Keywords: ritual actions, Ossetian hunter, Afsati, prayer, hunting staff.

Worldview attitudes practiced and transmitted by male communities to a significant extent affect the socialization of the individual, and, consequently, the development of the society. As a result, a comprehensive study of male subcultures is highly relevant. A subculture is always based on one or more previous subcultures that have changed under the influence of various factors. For this reason, to understand the ways of further development of modern society, it is important to study the previously existing subcultures. One of the basic elements of the subcultures of the past were ritual acts. Ritual actions had a pronounced external design and deep internal meaning. This work is aimed at the study of ritual actions and forms of the ritual behavior in the hunting subculture in the traditional Ossetian society. The subculture in question belongs to male professional subcultures. The influence of the values transmitted by it can be traced both in the spiritual and in the material culture of the Ossetian ethnos. The scientific novelty is determined by the fact that this work is the first comprehensive study of ritual actions in the Ossetian hunting subculture. Ethnographic material, folklore texts and data of the Ossetian language served as the sources for the development of the problem posed. In the study of the problem posed, the ritual and ceremonial forms of behavior of Ossetian hunters in different situations were considered. The features of the ritual behavior of the hunter guarding the camp while his comrades were hunting have been established. Ritual actions associated with a temporary hunting dwelling have been determined. The features of ritual behavior and the rite performed after a successful hunt are revealed. The ritual actions and rituals that were carried out by hunters in the settlement after hunting are highlighted. A ritual used by Ossetian hunters to remove the evil eye is described. This problem requires further in-depth research.

\section{REFERENCES}

1. Berzenov, N.G. Novyi god u osetin Vladikavkazskogo okruga [New Year of the Ossetians in the Vladikavkaz District] Periodicheskaya pechat'Kavkaza ob Osetii i osetinakh [Periodicals of the Caucasus about Ossetia and Ossetians]. Tskhinval, Iriston, 1981, vol. I, pp. 92-95.

2. Nartovskie skazaniya. Epos osetinskogo naroda [Nart legends. Epic of the Ossetian people]. Vladikavkaz, Iriston, 2003, book $1.589 \mathrm{p}$.

3. Tsagolov, G.M. Okhotnichii yazyk i obryady u osetin [Hunting language and rituals among the Ossetians]. Terskie vedomosti [Terskie vedomosti]. 1895, no. 58.

4. Chursin, G.F. Osetiny [Ossetians]. Yugo-Osetiya [South Ossetia]. Tiflis, 1924, pp. $132-232$.

5. Nauchnyi arkhiv SOIGSI [Scientific archive of the North-Ossetian Institute for Humanitarian and Social Studies]. Fund 19. Inventory 1. Case 140.

6. Kesaev, V.A. Obryady i yazyk osetinskikh okhotnikov [Rites and language of Ossetian hunters]. Vladikavkaz, Ir, 1998.148 p.

7. Magometov, A.Kh. Kul'tura i byt osetinskogo naroda [Culture and everyday life of the Ossetian people]. Ordzhonikidze, Ir, 1968. $556 \mathrm{p}$.

8. Kaloev, B.A. Osetiny [Ossetians]. Moscow, Nauka, 2004. 447 p.

9. Chibirov, L.A. Traditsionnaya dukhovnaya kul'tura osetin [Traditional spiritual culture of Ossetians]. Vladikavkaz, Ir, 2008. 599 p.

10. Tekhov, F.D. Okhotnichii yazyk u osetin [Ossetian hunting language]. Izvestiya YuONII [Proceedings of the South Ossetian Research Institute]. 1972, iss. 17, pp. 121-137.

11. Khadikova, A.Kh. Etnicheskie obrazy i traditsionnye modeli povedeniya osetin [Ethnic images and traditional models of behavior of Ossetians]. Vladikavkaz, North-Ossetian Institute for Humanitarian and Social Studies, 2015. 441p. 
12. Gagloeva, Z.D. Okhota v verovaniyakh i obychayakh osetin $i$ svanov [Hunting in the beliefs and customs of the Ossetians and Svans]. Izvestiya YuONII [Proceedings of the South Ossetian Scientific Research Institute]. 1987, iss. 31, pp 49-57.

13. Kusaeva, Z.K. Mifo-fol'klornye traditsii v osetinskoi literature [Mythological and folklor traditions in Ossetian literature]. Fundamental'nye issledovaniya [Fundamental research]. 2013, iss. 4-4, pp. 1005-1010. [electronic resource]. URL: http://fundamental-research.ru/ $\mathrm{ru} /$ article/view?id=31315

14. Khetagurov, K.L. Izbrannoe [Selected works]. Moscow, Goslitizdat, 1959. 479 p.

15. Bedoeva, I.A. Traditsionnye khmel'nye napitki osetin (XIX-XX vv.) [Traditional intoxicating drinks of Ossetians (XIX - XX centuries)]. Vladikavkaz, North-Ossetian Institute for Humanitarian and Social Studies, 2014. 176 p.

16. Kokiev, S.V. Zapiski o byte osetin [Notes on the life of Ossetians]. Periodicheskaya pechat' Kavkaza ob Osetii i osetinakh [Periodicals of the Caucasus about Ossetia and Ossetians]. Vladikavkaz, Ir, 2014, book 7, pp. 521-547.

17. Nartovskie skazaniya. Epos osetinskogo naroda [Nart legends. Epic of the Ossetian people]. Vladikavkaz, Iriston, 2005, book $3.712 \mathrm{p}$. 